\title{
CHARACTERIZATION OF SURFACE ACIDITY AND CATALYTIC ABILITY OF NATURAL CLAY MINERALS BY MEANS OF TEST CATALYTIC REACTION
}

\author{
Lyudmila NOVIKOVA ${ }^{1)}$ *, Larisa BELCHINSKAYA ${ }^{1)}$, \\ Frank ROESSNER ${ }^{2)}$ and Murad ALSAWALHA ${ }^{3)}$
}

\author{
1) Voronezh State Academy of Forestry and Technologies, 8 Timiryazeva str., 394087 Voronezh, \\ Russian Federation, chem@vglta.vrn.ru \\ ${ }^{2)}$ Carl von Ossietzky University of Oldenburg, Institute forChemistry, Industrial Chemistry 2, D-26111 \\ Oldenburg, Germany, frank.roessner@uni-oldenburg.de \\ ${ }^{3)}$ Jubail Industrial College, Department of Chemical \& Process Engineering Technology, PO Box 10099, \\ 31961 Jubail Industrial City, KSA, murad_s@jic.edu.sa \\ *Corresponding author's e-mail: novikov-la@yandex.ru
}

(Received March 2013, accepted August 2013)

\begin{abstract}
Catalytic test reaction of methylbutynol $(\mathrm{MBOH})$ conversion was applied to investigation of natural clays and non-clay minerals from Jordanian (bentonite, kaolinite, diatomite, zeolite) and Russian (palygorskite, kaolinite, hydromica) deposits as well as H-ZSM-5. Palygorskite and kaolinite containing samples have shown the highest catalytic activity. Conversion over Jordanian clay minerals decreased in the order: zeolite $>$ bentonite $>$ red kaolinite $>$ white kaolinite $>$ diatomite that agreed to change of acidity, surface area of samples. Sufficient deactivation was observed for H-ZSM-5, kaolinite and hydromica due to adsorption of secondary product in micropores of raw minerals. Products of both acidic and basic pathways of test reaction were formed indicating the presence of acid and basic sites on clays surface, apart from acidic catalyst H-ZSM-5. The yield ratio of acidic to basic products was above the unity for zeolite, bentonite, red kaolinite, and palygorskite; equal to unity for diatomite and hydromica, and less then unity for white kaolinite. It was observed for kaolinite containing sample that high activation temperature increased conversion of $\mathrm{MBOH}$ owing to formation of additional basic sites as a result of mineral dehydroxylation. Rise of montmorillonite content from 30 to $80 \%$ provided $91-97 \%$ of MBOH conversion.
\end{abstract}

KEYWORDS: test catalytic reaction; methylbutynol conversion; surface acidity; clay minerals

\section{INTRODUCTION}

It is well known that surface acidity of a solid is essential for heterogeneously catalyzed reactions, as well as for adsorption and ion-exchange processes (Adams and McCabe, 2006; Trombetta et al., 2000). Surface acidity of clay minerals characterizes their ability to donate a proton or an electron pair. Usually, it is described in terms of Broensted and Lewis sites which are represented by different surface groups and ions such as exchangeable cations, coordinatively unsaturated ions $\mathrm{Al}^{3+}, \mathrm{Mg}^{2+}, \mathrm{Fe}^{3+}$, acid/basic hydroxyl groups and oxygen anions (Schoonheydt and Johnston, 2006). Usually the number and type of surface sites of different solids, including clay minerals, are determined by using the probe molecules. Probe molecule is adsorbed on the surface and studied then by different physico-chemical methods, i.e. titration and spectroscopic techniques such as FTIR, XPS, NMR (Blanco et al., 1988; Sun Kou et al., 2000), along with temperature programmed desorption (TPD) of $\mathrm{NH}_{3}$ and $\mathrm{CO}_{2}$ (Okada et al., 2006; Trombetta, M., 2000; Ertl et al., 1997, Matsuhashi et al., 1994;), microcalorimetry (Ravichandran and Sivasankar, 1997), thermal analysis (Ruiz et al., 2002), etc. This type of molecule is so called non-reactive probe molecule (LauronPernot, 2006). On the other hand, application of catalytic reactions is based on the reactivity of a probe molecule and its ability to characterize surface sites. The most known catalytic test reactions are isopropanol conversion (Trombetta et al., 2000), dehydration of alcohols, cracking of cumene (Ravichandran et al., 1996) and benzene benzylation (Pushpaletha et al., 2005). Each of the techniques has its advantages and disadvantages. To the main advantages of using of model catalytic reaction belong: sensitivity of reaction to only reactive sites instead of nonreactive probe molecule adsorption in other techniques; operation even by the low number of sites; similar treatment of catalyst as in final practical application; reactive probe molecule is able to give different products produced by different sites (LauronPernot, 2006).

New powerful test reaction was suggested by (Lauron-Pernot et al., 1991) for clarification of active sites on the surface. Application of a tertiary alcohol 2-methyl-3-butin-2-ol (methylbutynol, denoted as $\mathrm{MBOH})$ as a probe molecule allows unambiguously 


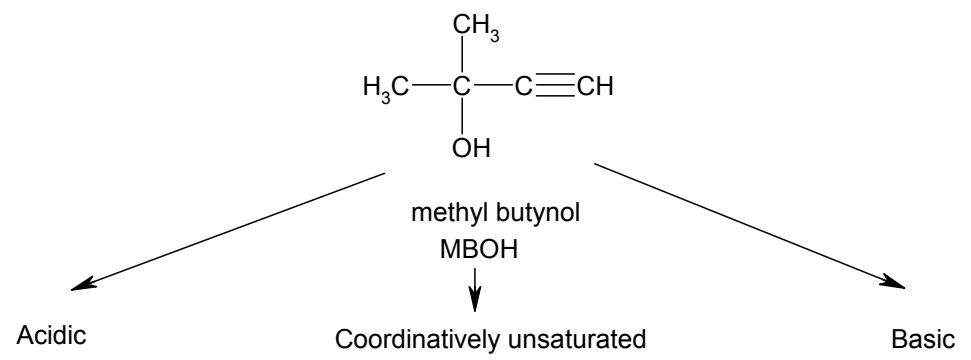<smiles>C#CC(=C)C</smiles>

3-methyl-3-buten-1-yne MBYNE<smiles>CC(C)=CC=O</smiles>

3-methyl-2-buten-1-al Prenal<smiles>CC(=O)C(C)(C)O</smiles>

2-hydroxy-2-methyl-3-butanone $\mathrm{HMB}$<smiles>C=C(C)C(C)=O</smiles>

3-methyl-3-buten-2-one MIPK

$$
\begin{aligned}
& \mathrm{H}_{3} \mathrm{C} \\
& \mathrm{H}_{3} \mathrm{C}
\end{aligned}>\mathrm{C}=\mathrm{O}
$$

acetone

$\mathrm{HC} \equiv \mathrm{CH}$

acetylene

Fig. 1 Scheme of methylbutynol conversion on different active sites of catalyst (adapted from Lauron-Pernot et al., 1991).

distinguish between several sites: acidic sites are responsible for formation of 3-methyl-3-buten-1-yne (MBYNE) or 3-methyl-2-buten-1-al (Prenal) whereas basic sites generate acetone and acetylene (Fig. 1).

Due to lack of techniques available for characterization of basic sites, test catalytic reaction of $\mathrm{MBOH}$ conversion is successfully used for basic sites, both basic and acid sites and even amphoteric centers assessment (Lauron-Pernot, 2006). The $\mathrm{MBOH}$ conversion was used for testing of zeolites by Huang and Kaliaguine (1993), as well as by Meyer and Hoelderich (1999), hydrotalcite-derived metal oxides by Kustrowski et al. (2004), whereas $\mathrm{MgO}$ by Chizallet et al. (2006). However, there are very few applications of the test reaction of methyl butynol conversion for investigation of natural clays and clay minerals (Novikova et al., 2006; AlSawalha et al., 2011).

The aim of present study was to characterize surface acidity and catalytic ability of various natural clay minerals and zeolites by test reaction of methylbutynol conversion.

\section{EXPERIMENTAL}

\subsection{MATERIALS}

Different samples of raw clays containing zeolite, bentonite, palygorskite, kaolinite, and diatomite were collected from National Resource Authority, Jordan (J) and several Russian deposits (R). Chemical composition of Jordanian clay samples (Table 1) was determined by X-ray Fluorescence (XRF) method (Abu Salah et al., 2002; Al-Ghouti et al., 2003). Chemical composition of Russian clays was determined using chemical analysis (Table 1).

Several samples from Russian deposits enriched with montmorillonite were studied as well. Phase compositions of montmorillonite containing clay minerals were as follows: 1 - montmorillonite $30 \%$, kaolinite $35 \%$, hydromica $35 \%$, quartz - traces; 2 montmorillonite $60 \%$, kaolinite $10 \%$, hydromica, quartz, feldspar - traces; 3 - montmorillonite $80 \%$, zeolite $15 \%$, hydromica $5 \%$.

The samples of clay minerals and zeolites were studied in a natural form without any preliminary treatment or purification. They were crashed and sieved into fraction 200-315 $\mu \mathrm{m}$. Samples of synthetic zeolite H-ZSM-5 $\left(\mathrm{SiO}_{2} / \mathrm{Al}_{2} \mathrm{O}_{3}=45\right)$ were used as reference catalyst (Cejka and Bekkum, 2005).

\subsection{TEST CATALYTIC REACTION OF METHYLBUTYNOL CONVERSION}

Catalytic conversion of methylbutynol (MBOH) over natural clay minerals was used for determination of surface acidity/basicity. Scheme for experimental set-up for methylbutynol conversion is presented in Figure 2, AlSawalha (2004).

Feed consisting of a mixture of $95 \%$ methylbutynol and $5 \%$ hexane was poured into a capillary and settled down in thermostat with temperature $13{ }^{\circ} \mathrm{C}$. Applying the static nitrogen pressure of $202.65 \mathrm{kPa}$ liquid $\mathrm{MBOH}$ was transported through the capillary with a rate of $0.2 \mathrm{~mL} / \mathrm{min}$ and evaporated in nitrogen flow. $0.1 \mathrm{~g}$ of catalyst was placed in the center of the reactor made from stainless steel. Prior to 
Table 1 Chemical composition and specific surface area (SSA) of natural clay minerals and zeolites

\begin{tabular}{|c|c|c|c|c|c|c|c|c|}
\hline \multirow{2}{*}{$\begin{array}{l}\text { Origin } \\
\text { Oxides } \\
\text { (\%wt.) }\end{array}$} & \multicolumn{3}{|c|}{ Russian deposits (R) } & \multicolumn{5}{|c|}{ Jordanian deposits (J) } \\
\hline & $\begin{array}{l}\text { Palygorskit } \\
\text { e } \sim 50 \%, \\
\text { quartz, } \\
\text { zeolite, } \\
\text { mica, } \\
\text { feldspar }\end{array}$ & $\begin{array}{c}\text { Kaolinite - } \\
60 \% ; \\
\text { hydromica } ~ \\
30 \%, \\
\text { montmorillo } \\
\text { nite } \sim 10 \%\end{array}$ & $\begin{array}{c}\text { Hydromica- } \\
35 \%, \\
\text { clinoptilolite- } \\
5 \%, \\
\text { kaolinite-5\%, } \\
\text { quartz, mica- } \\
\text { traces }\end{array}$ & $\begin{array}{c}\text { Zeolite- } \\
\text { (major- } \\
\text { phillipsite, } \\
\text { chapazite, } \\
\text { faujasite) }\end{array}$ & $\begin{array}{c}\text { Bentonite } \\
\text { smectite } \\
10 \%, \\
\text { illite, } \\
\text { feldspar, } \\
\text { quartz }\end{array}$ & $\begin{array}{c}\text { White } \\
\text { Kaolinite } \\
\text { 60\%, } \\
\text { (minor- } \\
\text { quarz, } \\
\text { mica, } \\
\text { feldspar, } \\
\text { gypsum) }\end{array}$ & $\begin{array}{c}\text { Red } \\
\text { Kaolinite } \\
\text { 30\%, } \\
\text { (minor- } \\
\text { quarz, } \\
\text { mica, } \\
\text { feldspar, } \\
\text { gypsum) }\end{array}$ & $\begin{array}{c}\text { Diatomite, } \\
\text { traces of } \\
\text { kaolinite, } \\
\text { illite, } \\
\text { quartz }\end{array}$ \\
\hline $\mathrm{SiO}_{2}$ & 53.25 & 50.48 & 48.54 & 42.00 & 55.70 & 48.00 & 47.60 & 72.00 \\
\hline $\mathrm{Al}_{2} \mathrm{O}_{3}$ & 9.84 & 18.21 & 11.24 & 12.80 & 20.10 & 36.30 & 24.90 & 11.40 \\
\hline $\mathrm{Fe}_{2} \mathrm{O}_{3}$ & 7.68 & 6.84 & 0.86 & 12.10 & 1.50 & 1.00 & 6.10 & 5.80 \\
\hline $\mathrm{FeO}$ & 0.61 & 0.27 & -- & -- & -- & -- & -- & -- \\
\hline MgO & 7.95 & 1.80 & 1.10 & 10.10 & 3.50 & 0.30 & 1.00 & -- \\
\hline $\mathrm{CaO}$ & 3.62 & 1.96 & 9.78 & 8.50 & 2.10 & 0.10 & 0.50 & 1.50 \\
\hline \multirow[t]{2}{*}{$\mathrm{Na}_{2} \mathrm{O}$} & & $\mathrm{Na}_{2} \mathrm{O}+\mathrm{K}_{2} \mathrm{O}$ & & 4.00 & 0.10 & 0.10 & 0.80 & 7.20 \\
\hline & 0.86 & 0.35 & 4.12 & & & & & \\
\hline $\mathbf{K}_{2} \mathbf{O}$ & & & & 0.80 & 2.40 & 1.80 & 2.30 & -- \\
\hline $\mathrm{TiO}_{2}$ & -- & -- & -- & -- & 2.50 & 0.10 & 0.70 & -- \\
\hline$\frac{\mathrm{SiO}}{\mathrm{Al}_{2} \mathrm{O}_{3}+\mathrm{Fe}_{2}} \frac{2}{\mathrm{O}_{3}}$ & 2.77 & 2.01 & 5.41 & 1.69 & 2.58 & 1.29 & 1.54 & 4.19 \\
\hline SSA & $146.3^{*}$ & $35.4^{*}$ & $24.1^{*}$ & $96.3 * *$ & $70.2 * *$ & $41.9^{* * *}$ & $45.2^{* *}$ & $39.4 * *$ \\
\hline
\end{tabular}

* Novikova et al., 2006, ** Alsawalha et al., 2011.

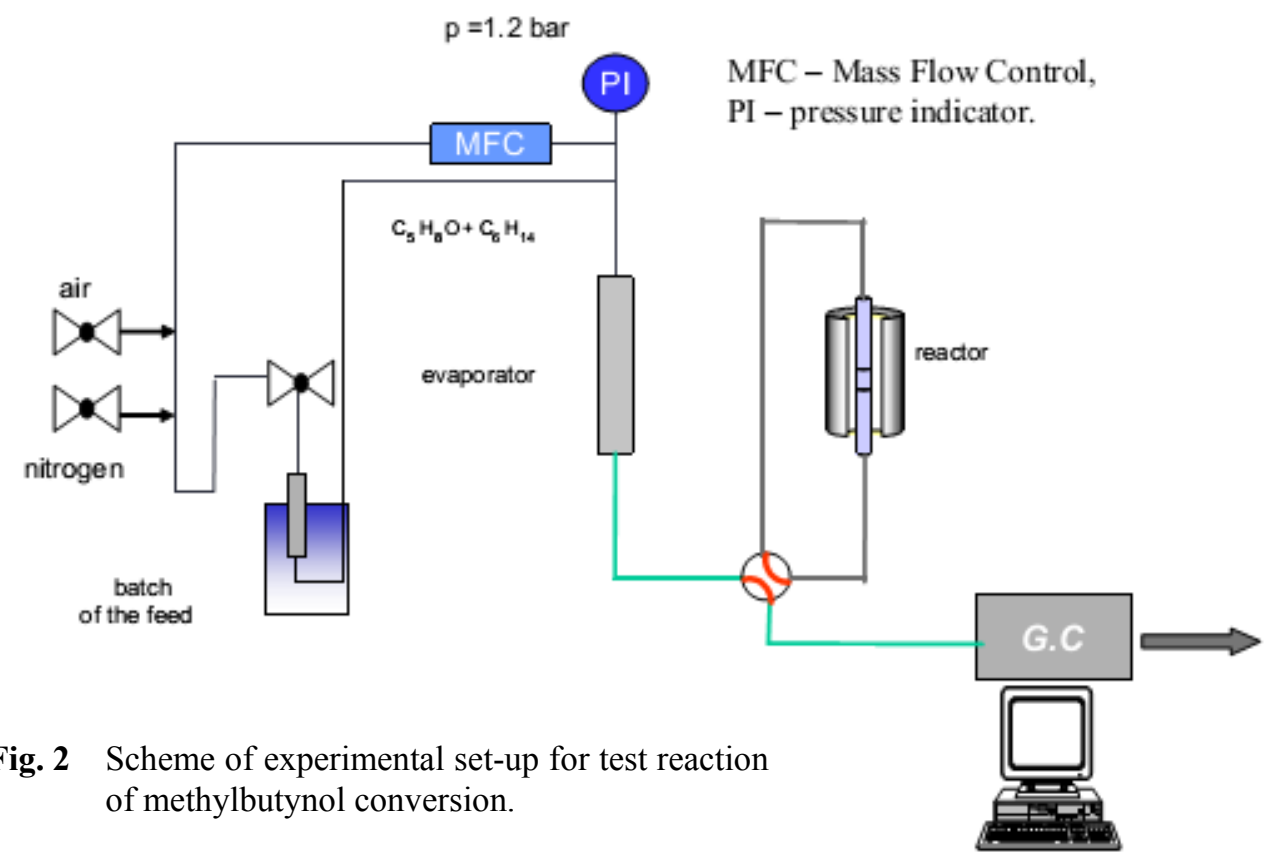

reaction catalyst activation was carried out in a stream of nitrogen at $500{ }^{\circ} \mathrm{C}$ during 4 hours in order to remove water and $\mathrm{CO}_{2}$ from the surface.

After the activation of catalyst reactor was cooled down till the temperature of reaction $\left(120^{\circ} \mathrm{C}\right)$. The products of reaction were analyzed on-line using a gas chromatograph Hewlett-Packard 5890 supplied by a capillary column (Optima Wax, MachereyNagel). Correlation of the peak areas and response- factors of substances defined by gas chromatograph was experimentally determined by AlSawalha (2004).

The quantity of products was calculated by comparing the registered peak area with the peak area of hexane which was used as an internal standard. Furthermore, conversion of $\mathrm{MBOH}(\mathrm{X}, \%)$ and yield of products $\left(\mathrm{Y}_{\mathrm{p}}\right.$, mol. \%) were calculated accordingly to the following equations: 
$\mathrm{X}_{\mathrm{MBOH}}, \%$

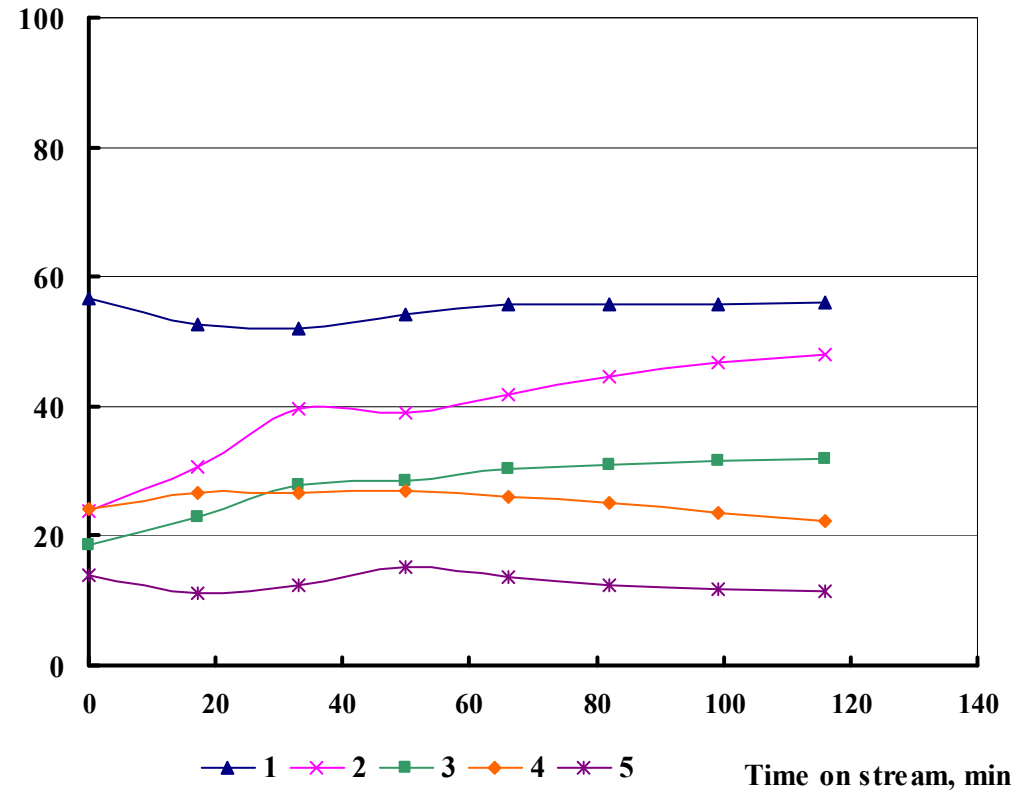

Fig. 3 Conversion of methylbutynol over Jordanian clay minerals and zeolite at $120{ }^{\circ} \mathrm{C}$ : 1 - zeolite, 2 - bentonite, 3 - red kaolinite, 4 - white kaolinite, 5 - diatomite.

$$
\begin{aligned}
& X_{M B O H}(\%)=\frac{n_{M B O H, \text { in }}-n_{M B O H, \text { out }}}{n_{M B O H, \text { in }}} \cdot 100, \\
& Y_{P}(\%)=\frac{A_{p} R_{p} / M_{p}}{\sum_{k} A_{k} R_{k} / M_{k}} \cdot 100,
\end{aligned}
$$

where $\mathrm{n}_{M B O H \text {,in }}$ and $\mathrm{n}_{M B O H, \text { out }}$ are the number of moles of $\mathrm{MBOH}$ at the input and outlet stream of reactor; $A_{P}, A_{K}$ and $R_{P}, R_{K}$ represent the peak areas and response factors of compounds $\mathrm{P}$ and $\mathrm{K}$, respectively. $\mathrm{M}_{\mathrm{P}}, \mathrm{M}_{\mathrm{K}}$ is molecular weight of $\mathrm{P}$ and $\mathrm{K}$, respectively.

\section{RESULTS AND DISCUSSION}

\subsection{CONVERSION OF METHYLBUTYNOL ON NATURAL ALUMOSILICATES}

The time on stream behavior of the investigated natural alumosilicates from Jordanian and Russian deposits are presented in Figures 3 and 4.

It follows from Figure 3 that degree of $\mathrm{MBOH}$ conversion over Jordanian clay samples decreases in the following order: zeolite $>$ bentonite $>$ red kaolinite $>$ white kaolinite $>$ diatomite, which is the order for specific surface area of these aluminosilicates. Catalytic activity of Jordanian zeolite and diatomite during $\mathrm{MBOH}$ conversion remained relatively constant, whereas a slight increase of conversion on time was observed for bentonite, red and white kaolinite.

Clay minerals from Russian deposits proved sufficiently higher catalytic ability to convert $\mathrm{MBOH}$ despite the deactivation (Fig. 4). In this group of samples the highest conversion of methylbutynol was observed for palygorskite, and the lowest for hydromica and H-ZSM-5. Specific surface area (Table 1) and porosity of these catalysts change in a row: palygorskite $>$ kaolinite- $\mathrm{R}>$ hydromica (Novikova et al., 2006) correlating to corresponding values of methylbutynol conversions. The reasons for sufficient deactivation of H-ZSM-5, kaolinite and hydromica from Russian deposits since the initial stage of reaction could be related to strong adsorption of secondary products and irreversible surface modification (Lauron-Pernot, 2006). Moreover, FTIRspectra proved formation of polyaromatic compounds and coke on the surface of H-ZSM-5 due to acid catalyzed polymerization of $\mathrm{MBOH}$ (Lauron-Pernot, 2006). Microporosity of zeolite and natural admixtures of quartz and micas in raw clay samples strengthen this effect.

The highest catalytic activity of palygorskite among the Russian and Jordanian clay minerals is explained by high content of this mineral in clay sample and the unique needle-like structure of mineral providing high surface area of catalyst and accessibility of active sites for substrate molecules.

Comparison of the catalytic ability of both groups of samples from Russian and Jordanian deposits gives a general sequence for values of $\mathrm{MBOH}$ conversion: palygorskite $>$ kaolinite- $\mathrm{R}>$ zeolite- $\mathrm{J}>$ bentonite- $\mathrm{J}>$ hydromica $>$ red kaolinite $>$ H-ZSM-5 $>$ white kaolinite $>$ diatomite. However, as a whole this row does not correlate to surface area or $\mathrm{Si} / \mathrm{Al}$ ratio of samples due to differences in chemical composition of minerals, containing various structural components having different catalytic ability. The catalytic activity revealed by samples of natural alumosilicates depends most likely on content of the porous component as zeolite one. 


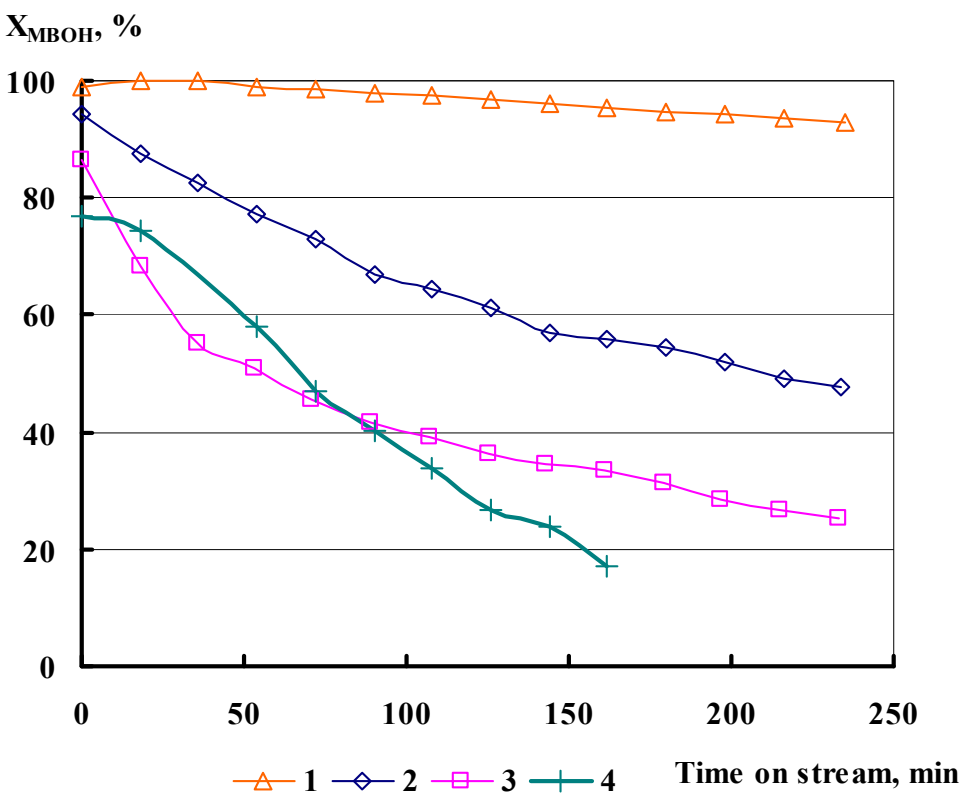

Fig. 4 Conversion of methylbutynol over Russian clay minerals and zeolite at $120^{\circ} \mathrm{C}$ :

1 - palygorskite, 2 - kaolinite, 3 - hydromica; 4 - H-ZSM-5.

It is essential to note that application of high temperatures for activation of such clay catalysts as palygorskite, bentonite and kaolinite causes not only the loss of the hygroscopic, zeolitic and crystal waters, $\mathrm{CO}_{2}$, but also partially destroys or collapse their layered structure (Heller-Kallail, 2006) followed by a strong decrease in adsorption ability (Belchinskaya, 2002 ) and changes in catalytic properties (Adams and McCabe, 2006). For example, folding of channel structure for palygorskite starts above the $\mathrm{T}=300{ }^{\circ} \mathrm{C}$ forming the palygorskite anhydride (Chen et al., 2006), keeping its layered-band morphology up to $800{ }^{\circ} \mathrm{C}$. Furthermore, thermal treatment at $550{ }^{\circ} \mathrm{C}$ lead to maximal values of surface area and total pore volume of palygorskite followed by sufficient decrease in surface characteristics while heating at $750{ }^{\circ} \mathrm{C}$ (Frini-Srasra and Srasra, 2008). According the Bayram, et al., 2007 reversible folding of nanochannels of palygorskite takes place by heating up to $400{ }^{\circ} \mathrm{C}$, whereas at 500 and $600{ }^{\circ} \mathrm{C}$ irreversible folding of structure occurs. In case of Jordanian bentonite heating right up to $500{ }^{\circ} \mathrm{C}$ leads to the possibility of reversible hydration of the mineral (Sarikaya et al., 2000). It is supposed that water formed along the reaction causes clay swelling that makes for structural rearrangements of clays and makes internal acidic sites more accessible (AlSawalha et al., 2011). Calcination of kaolinite, a 1:1 clay mineral, results in its transformation to partially amorphous phase of metakaolinite, which acidity/basicity is varied by regimes of heating, providing material an ability to act as a super acid under certain condition (Macedo et al., 1994).
These transformations of alumosilicates structures caused by thermal treatment lead to alteration of their surface acidity/basicity due to formation of strong acid/basic sites on the surface (Dong Liu et al., 2011). Figures $5 \mathrm{a}$ and $5 \mathrm{~b}$ summarizes the yields of products in reaction of methylbutynol conversion for the investigated natural alumosilicates.

As it follows from the Figures $5 \mathrm{a}$ and $5 \mathrm{~b}$, the typical products of $\mathrm{MBOH}$ conversion over studied clay minerals are MBYNE, prenal, acetone and acetylene apart from synthetic zeolite H-ZSM-5. Formation of MBYNE and prenal illustrates the presence of acid centers on the surface of catalyst while formation of acetone and acetylene is a characteristic for basic centers. According to many authors (Tarasevich, 1988; Azzouz et al., 2004; Kaya, 2004), there is no clay having only acidic or basic properties, because both types of sites are present on the surface and transforms to each other under definite conditions such as water content, $\mathrm{pH}$, etc.

The ratio between the acidic and basic products differs from the type of clay sample. According to Figure 5 yields of MBYNE and prenal exceed yield of acetylene and acetone during the methyl butynol conversion over zeolite, palygorskite, bentonite and kaolinite. This fact shows, apparently, that number or/and strength of acid centers on the surface of given samples of clay minerals and zeolite exceeds number/strength of basic centers. Indeed, TPD- $\mathrm{NH}_{3}$ and $\mathrm{CO}_{2}$ studies of acidity and basicity distribution for natural and ion-exchanged montmorillonites revealed that acidity level is 2-3 times higher than that for basicity, regardless to the cation introduced on the clay surface (Azzouz et al., 2004). Alkaline cations 


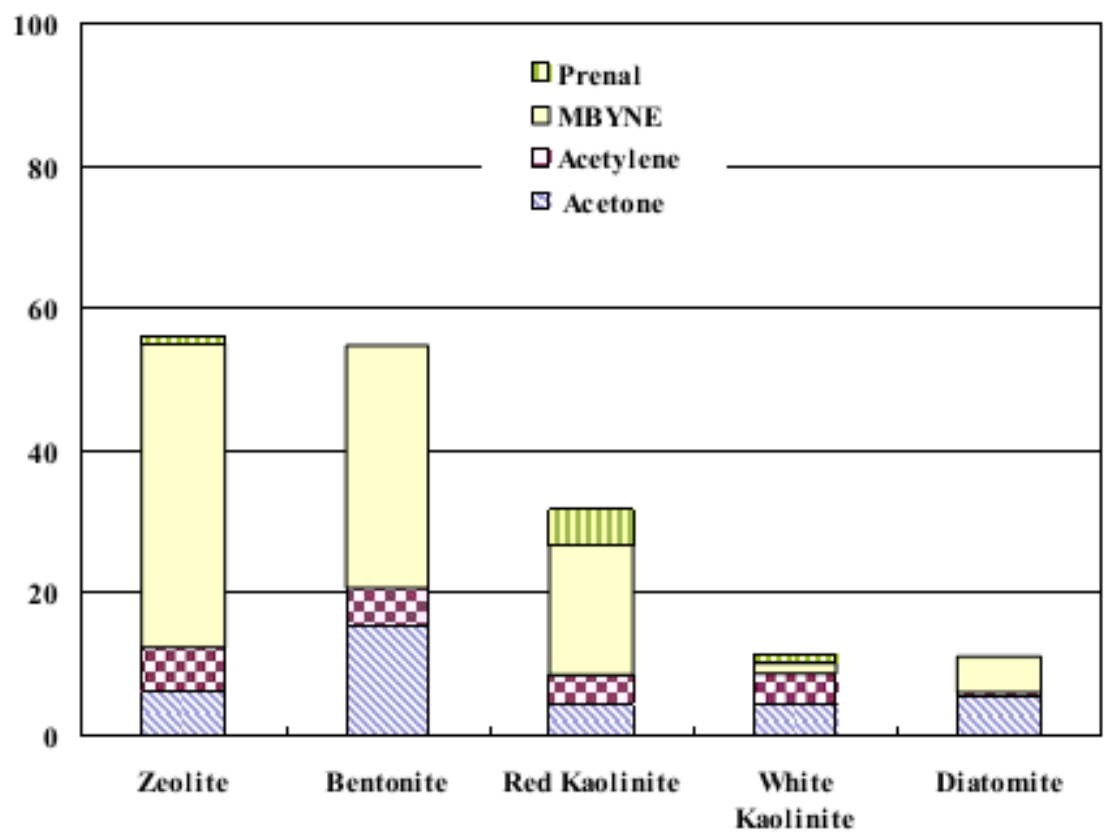

Yield of products, $\operatorname{mol} \%$

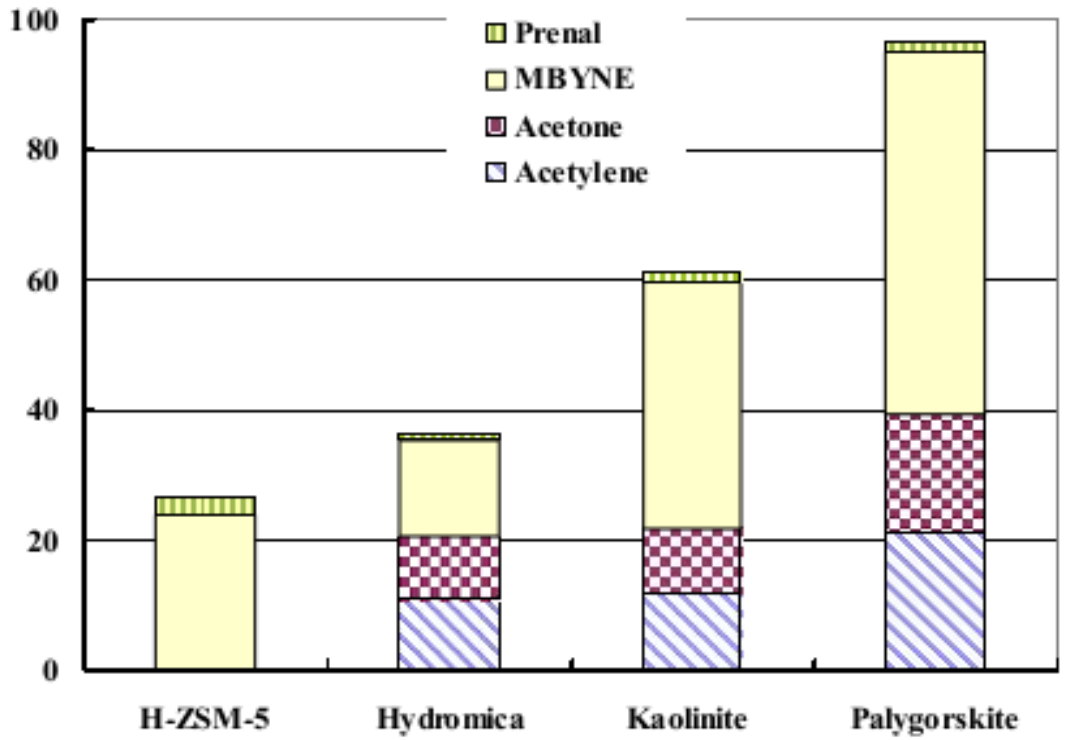

Fig. 5 Yield of products in reaction of $\mathrm{MBOH}$ conversion on Jordanian (5a) and on Russian (5b) clay minerals and zeolite ZSM-5, time on stream 116 min

confer to clays low acidity, and weak acid strength, in comparison to alkaline-earths.

In case of kaolinite the contribution of acidic and basic sites should be comparable due to its weak natural structural acidity caused by low isomorphic substitution of low valence cations for higher valence cations mainly in the tetrahedral sheet. $\mathrm{AlOH}$ groups of basic character located at side edges of crystals cover about $45 \%$ of total kaolinite surface (Tarasevich, 1988) resulting in its ability to adsorb both acidic and basic molecules almost equally (Kaya, 2004). However, presence of montmorillonite and hydromica along with kaolinite in natural sample explains higher yield of acidic products.

Earlier it was proved by TPD-NH $\mathrm{N}_{3}$ that acidity of Jordanian alumosilicates decreases in row: zeolite $>$ bentonite $>$ red kaolinite $>$ diatomite $>$ white kaolinite (Alsawalha et al., 2011). However, sufficient amounts of basic products formed during $\mathrm{MBOH}$ conversion prove essential contribution of basic centers to the general concentration of surface centers, except for HZSM-5. Furthermore, the energy of activation for the basic pathway is slightly higher as for acidic one $\left(\mathrm{E}_{\mathrm{A}}=45.8 \mathrm{~kJ} / \mathrm{mol}\right.$ and $\mathrm{E}_{\mathrm{A}}=79.4 \mathrm{~kJ} / \mathrm{mol}$, respectively) as 

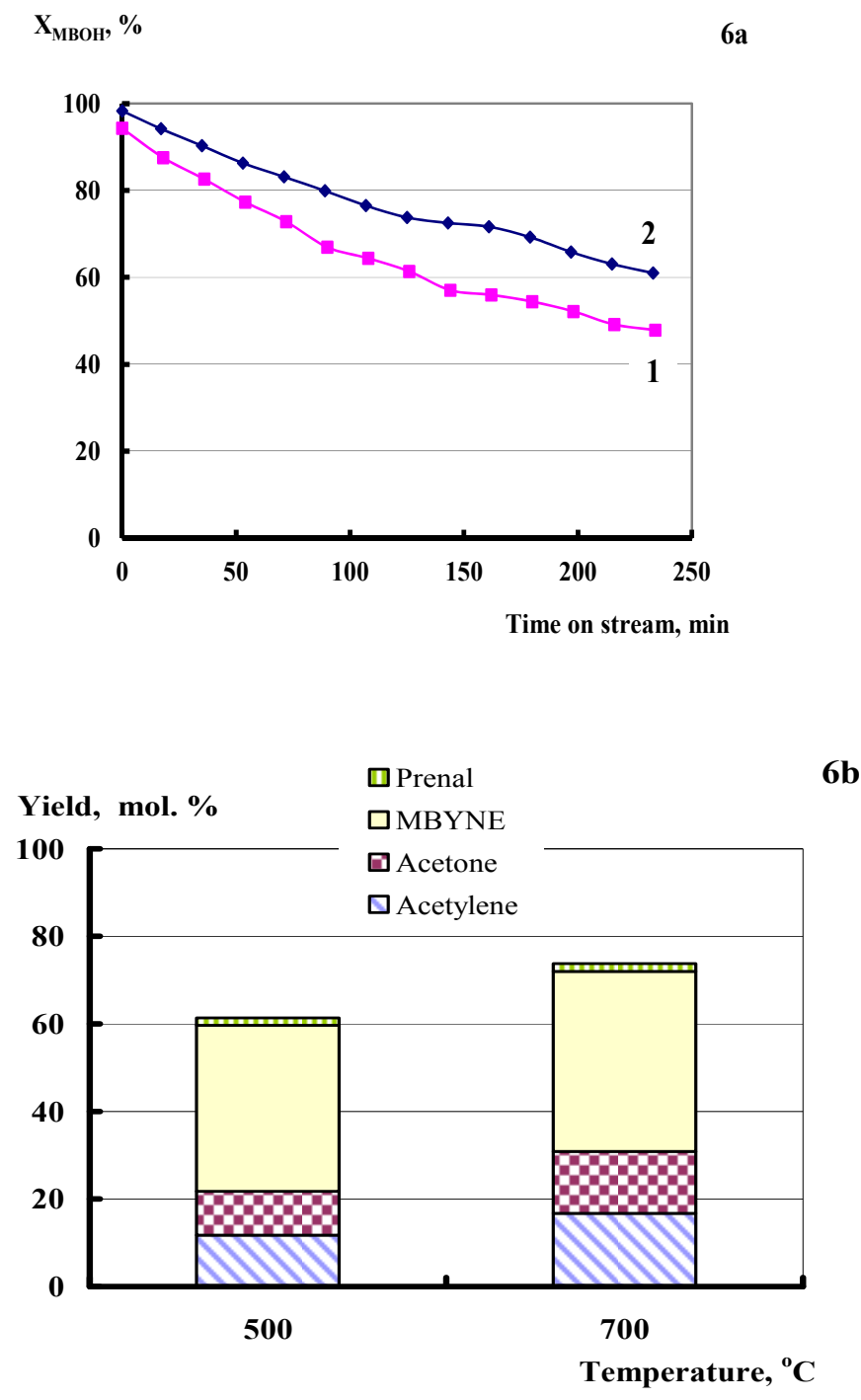

Fig. 6 Conversion (6a) and yield of products (6b) in reaction of $\mathrm{MBOH}$ conversion on natural kaolinite activated at $500{ }^{\circ} \mathrm{C}$ (1) and $700{ }^{\circ} \mathrm{C}(2)$ (t.o.s $=126$ min, $\mathrm{t}_{\text {react }}=120^{\circ} \mathrm{C}$ ).

calculated for the conversion of $\mathrm{MBOH}$ on silicaalumina and hydrotalcite, (AlSawalha and Roessner, 2008).

According to reaction mechanism, considered by AlSawalha and Roessner (2008) in detail, $\mathrm{SiOH}$ groups are acidic centers and oxygen anions $\mathrm{O}^{-}$are basic centers on the surface of catalyst. As expected from the structure of zeolite $\mathrm{H}-\mathrm{ZSM}-5$ and from its high value of ratio $\mathrm{SiO}_{2} / \mathrm{Al}_{2} \mathrm{O}_{3}$ equal to 45 , entirely products of the acidic pathway are formed. Origin of basic properties of natural clay minerals, for which acidic properties are more characteristic, is related to formation of Lewis basic sites during dehydroxylation process taking place at catalyst activation at $500{ }^{\circ} \mathrm{C}$. Upon heating silanol groups $\mathrm{Si}-\mathrm{OH}$ transform into siloxane one $\mathrm{Si}-\mathrm{O}-\mathrm{Si}$, in which $\mathrm{O}$ - ions are able to act as Lewis bases. Other reactions such as carbonates decomposition take place as well, yielding $\mathrm{MgO}$ and $\mathrm{CaO}$ and providing additional basic sites.
The highest basicity observed for samples of palygorskite is related to its mainly $\mathrm{MgOH}$ groups that allows using palygorskite as a basic catalyst (Hattori, H., 1995).

In the case of hydromica the yield of acid and basic products was practically identical. Therefore, the concentration of acid and basic centers on the surface of hydromica seems to be comparable. Natural hydromicas, as non-expanding clay minerals, possess low Broensted acidity due to absence or very low hydration of an interlayer exchangeable cation. Its catalytic activity originates from cation sites on external basal surfaces (Zhibin Wei et al., 2006), as well as from surface sites of clinoptilolite and montmorillonite presenting in the samples.

The lowest conversion and product yields in case of diatomite were caused most likely by its low acidity (Yuan et al., 2004; Alsawalha et al., 2011) due to low polarization of $\mathrm{Si}-\mathrm{OH}$ groups, which were 

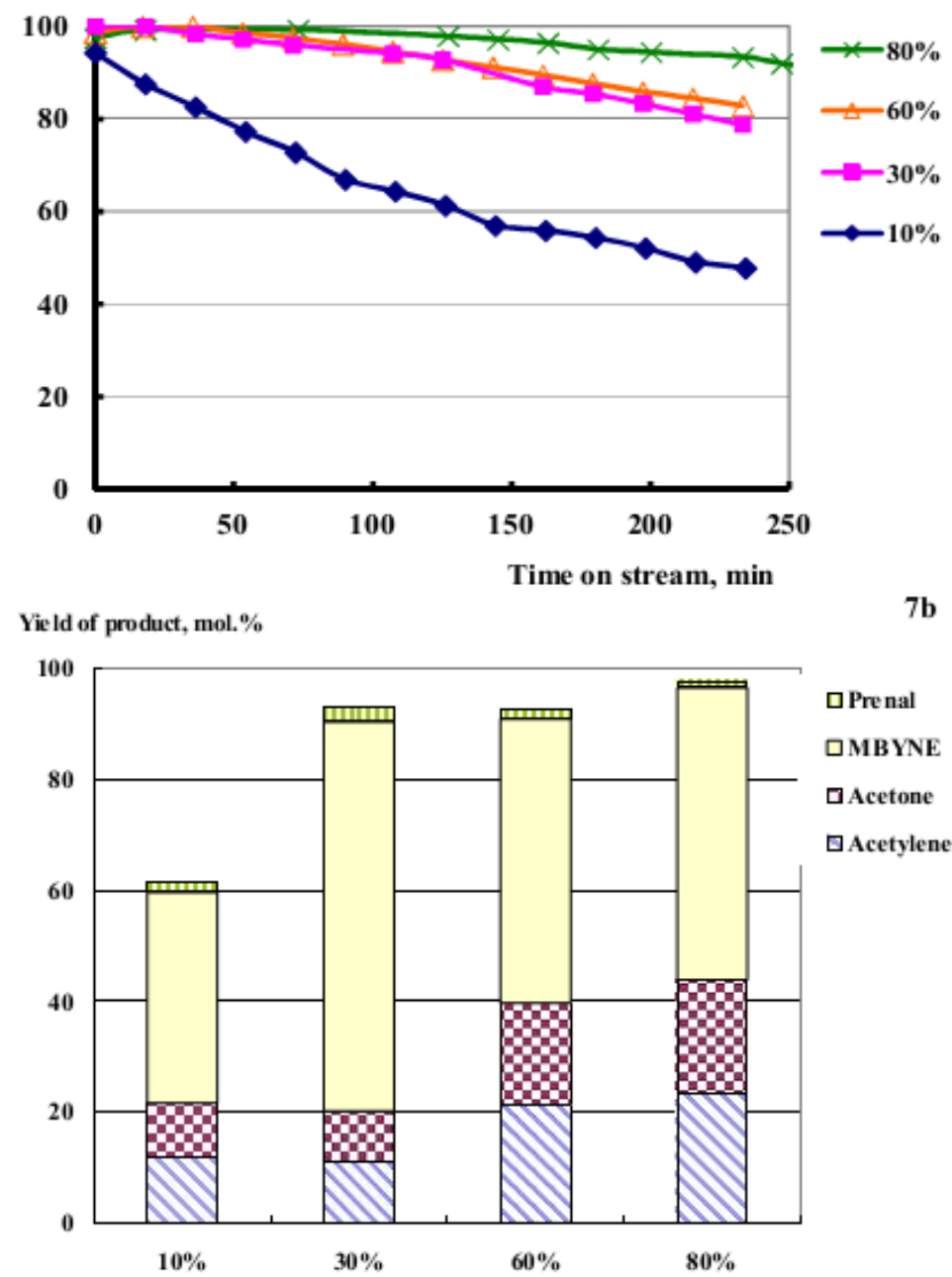

Fig. 7 Conversion (7a) and yield of products (7b) in reaction of $\mathrm{MBOH}$ conversion on clay minerals with different content of montmorillonite $\left(\mathrm{m}=0.1 \mathrm{~g} ; \mathrm{t}_{\text {react. }}=120{ }^{\circ} \mathrm{C} ; \mathrm{t}_{\text {cond. }}=500{ }^{\circ} \mathrm{C}\right)$.

partially transformed into siloxane groups by the thermal treatment (Fubini et al., 1995).

\subsection{INFLUENCE OF THE TEMPERATURE OF CATALYST ACTIVATION ON ACIDITY/BASICITY OF ALUMOSILICATE}

Among the whole studied alumosilicates the sample of kaolinite from Russian deposit, containing also $30 \%$ of hydromica and $10 \%$ of montmorillonite, provided relatively high conversion of $\mathrm{MBOH}$, which, at the same time, did not exceed the one provided by palygorskite. It is noteworthy that kaolinite is a widely spread mineral, which is concomitant, along with hydromica, to other alumosilicates in various deposits. In order to track changes of surface acidity/basicity of kaolinite as well as its catalytic ability towards $\mathrm{MBOH}$ conversion we carried out catalyst activation at a higher temperature $\left(700{ }^{\circ} \mathrm{C}\right)$.

Figures $6 \mathrm{a}$ and $6 \mathrm{~b}$ show data on methylbutynol conversion and yields of products for the conversion on natural kaolinite activated at 500 and $700{ }^{\circ} \mathrm{C}$, respectively.
It is evident from Figure 6a that the increase of activation temperature resulted in a higher degree of methylbutynol conversion. The yields of acidic products remained practically constant whereas yield of acetone and acetylene formed via basic reaction pathway increased (Fig. 6b). This result can be explained by formation of additional number of basic sites on the surface due to mineral dehydroxylation at temperatures $\mathrm{T} \geq 700{ }^{\circ} \mathrm{C}$ (Sarikaya et al., 2000; HellerKallail, 2006).

\subsection{INFLUENCE OF MONTMORILLONITE CONTENT ON CATALYTIC PROPERTIES OF CLAY MINERALS}

Natural clay samples from Russian deposits with different content of montmorillonite were tested in reaction of $\mathrm{MBOH}$ conversion in order to compare their surface acidity. Figures $7 \mathrm{a}$ and $7 \mathrm{~b}$ represents experimental values of methylbutynol conversion and yield of products for natural clay minerals containing $10-80 \%$ of montmorillonite. 
Figure 7a demonstrates that increase in content of montmorillonite in natural mineral caused higher conversion of methylbutynol on the active centers of minerals. The reaction ran via both acidic and basic pathway of $\mathrm{MBOH}$ conversion forming MBYNE, acetylene and acetone as main products. The acidity of montmorillonite slightly growed by the increase of mineral content except for the sample having $30 \%$ of mineral content and revealing the highest acidity of surface. The overall increase in montmorillonite content as well as due to influence of other concomitant minerals (kaolinite, hydromica, zeolite) surface basicity of the samples raised about two times and surface acidity by 1.5 times.

Note, that already at a content of $30 \%$ of montmorillonite in the sample the value of methylbutynol conversion was close to the thermodynamic equilibrium. Consequently, a further increase in content of montmorillonite to 60 and $80 \%$ did not give high values of conversion but only changed the selectivity towards basic products. The sample with $10 \%$ content of montmorillonite underwent earlier and significant deactivation in comparison with the samples enriched with montmorillonite. This situation could be explained by less quantity of transport pores in the samples with low content of clay mineral (Novikova et al., 2005).

\section{CONCLUSIONS}

Catalytic test reaction of methylbutynol conversion has shown presence of both acidic and basic centers on the surface of different clay minerals and zeolites from various deposits. Surface acidity/basicity as well as catalytic activity was affected by natural structure of mineral, mineral content and temperature of catalyst activation. Higher values of both acidity and catalytic activity were obtained for palygorskite, a mineral with layered-band structure, treated at high activation temperatures. Increase in natural basicity of surface of rich with montmorillonite samples or formation of additional basic sites (O- atoms) by high activation temperature of catalysts were the reasons of growth of $\mathrm{MBOH}$ conversion.

Natural zeolites and zeolite ZSM-5 revealed lower catalytic effect and strong deactivation as a result of their low content and/or microporous structure.

\section{ACKNOWLEDGMENTS}

L.N and M.A. are gratefully acknowledged to the German Academic Exchange Service (DAAD) and the Russian Ministry of Education and Science for visiting grant within the framework programme "Michael Lomonosov".

\section{REFERENCES}

Abu Salah, N., Mehyar, A., Al-Rousan, K., Tarawneh, M., Nawasreh, E. and Abu Arar: 2002, Natural Resources Authority, Arabic Report, Jordan, 120-126.
Adams, J.M. and McCabe, R.W.: 2006, Clay minerals as catalysts in: Bergaya, F., Theng, B.K.G., Lagaly, G., Handbook of Clay Science. Developments in Clay Science, 1. Elsevier Ltd., 547-552.

Al-Ghouti, M., Khraisheh, M.A.M., Allen, S.J. and Ahmad, M.N.: 2003, The removal of dyes from textile wastewater: a study of the physical characteristics and adsorption mechanisms of diatomaceous earth. J. Env. Manag., 69, 229-238.

DOI: $10.1016 /$ j.jenvman.2003.09.005

AlSawalha, M.: 2004, Characterization of acidic and basic properties of heterogeneous catalysts by test reactions. Ph.D. thesis, Carl von Ossietzky Universitat, Oldenburg, Germany.

Alsawalha, M. and Roessner, F.: 2008, Insight in to the reaction mechanism of the conversion of methylbutynol on silica-alumina. React. Kinet. Catal. Lett., 94 (1), 63-69. DOI: 10.1007/s11144-008-5249-y

AlSawalha, M., Roessner, F., Novikova, L. and Bel'chinskaya, L.: 2011, Acidity of different Jordanian clays characterized by TPD-NH3 and $\mathrm{MBOH}$ conversion. World Academy of Science, Engineering and Technology, 79, 417-421.

Azzouz, A., Niquette, P., Asaftei, S., Monette, F., Hausler, R., Nistor, D. and Miron, D.: 2004, Acid-base properties of montmorillonite and interactions with enzymes through REM investigations. Sciences \& Technologie A, 22. 89-96.

Bayram, H., Oenal, M., Ustun, G. and Sarikaya, Y.: 2007, Some thermal characteristics of a mineral mixture of Palygorskite, metahalloysite, magnesite and dolomite. J. Therm. Anal. Calorim., 89 (1), 169-174. DOI: $10.1007 / \mathrm{s} 10973-006-7561-y$

Belchinskaya, L.: 2002, Environment protecting technologies for neutralization and recycling of wastes from furniture industries (in Russian), Voronezh State Forestry Engineering Academy, Voronezh, 210 pp.

Blanco, C., Herrero, J., Mendioroz, S. and Pajares, J.A.: 1988, Infrared studies of surface acidity and reversible folding in Palygorskite. Clay. Clay. Miner., 36 (4), 364-368. DOI: 10.1346/CCMN.1988.0360412

Cejka, J. and Bekkum, H.: 2005, Zeolites and ordered mesoporous materials: progress and prospects. Studies in Surface Science and Catalysis, 157.

Chen, T., Wang, J., Qing, C., Peng, S., Song, Y. and Guo, Y.: 2006,. Effect of heat treatment on structure, morphology and surface properties of Palygorskite. J. Chinese Ceramic Soc. DOI: CNKI:SUN:GXYB.0.2006-11-023

Chizallet, C., Costentin, G., Lauron-Pernot, H., Krafft, J.M., Bazin, P., Saussey, J., Delbecq, F., Sautet, P. and Che, M.: 2006, Role of Hydroxyl Groups in the Basic Reactivity of MgO: a Theoretical and Experimental Study. Oil \& Gas Science and Technology - Rev. IFP, 61 (4) 479-488. DOI: 10.2516/ogst:2006023a

Dong, Liu et al.: 2011, Influence of heating on the solid acidity of montmorillonite: A combined study by DRIFT and Hammett indicators. Appl. Clay Sci., 52 (4), 358-363. DOI: 10.1016/j.clay.2011.03.016

Ertl, G., Knozinger, H. and Weitkamp, J.: 1997, Handbook of heterogeneous catalysis, $1,426 \mathrm{pp}$.

Frini-Srasra, N. and Srasra, E.: 2008, Effect of Heating on Palygorskite and Acid Treated Palygorskite Properties. Surf. Eng. Appl. Elect., 44 (1), 43-49. DOI: $10.3103 / \mathrm{S} 1068375508010092$

Fubini, B., Bolis, V., Cavenago, A. and Volantel, M.: 1995, Physicochemical properties of crystalline silica dusts 
and their possible implication in various biological responses. Scand. J. Work. Environ. Health. 21, 9-14.

Hattori, H.: 1995, Heterogeneous basic catalysis. Chem. Rev., 95, 537-558. DOI: 10.1021/cr00035a005

Heller-Kallail, L.: 2006, Thermally modified clay minerals in: Bergaya, F., Theng, B.K.G., Lagaly, G., Handbook of Clay Science. Developments in Clay Science (1). Elsevier Ltd., 289-308.

Huang, M. and Kaliaguine, S.: 1993, Reactions of methylbutynol on alkali-exchanged zeolites. A Lewis acid-base selectivity study, Catalysis Letters, 18 (4), 373-389. DOI: 10.1007/BF00765284

Kaya, A.: 2004, Characterization of clay particle surfaces for contaminant sorption in soil barriers Using Flow Microcalorimetry. J. Environ. Eng. 130, Spcial issue: Waste containment barrier materials, 918-921. DOI: 10.1061/(ASCE)0733-9372(2004)130:8(918)

Kustrowski, P., Chmielarz, L., Bozek, E., Sawalha, M. and Roessner, F.: 2004, Acidity and basicity of hydrotalcite derived mixed $\mathrm{Mg}-\mathrm{Al}$ oxides studied by test reaction of $\mathrm{MBOH}$ conversion and temperature programmed desorption of $\mathrm{NH}_{3}$ and $\mathrm{CO}_{2} /$ Materials research Bulletin, 39, 263-281.

DOI: $10.1016 /$ j.materresbull.2003.09.032

Lauron-Pernot, M., Luck, F. and Popa, J.M.: 1991, Methylbutynol: a new and simple diagnostic tool for acidic and basic sites of solids. Applied Catalysis, 78, 213-225. DOI: 10.1016/0166-9834(91)80107-8

Lauron-Pernot, H.: 2006, Evaluation of surface acido-basic properties of inorganic-based solids by model catalytic alcohol reaction networks. Catalys. Rev., 48, 315-361. DOI: 10.1080/01614940600816634

Macedo, J.C.D., Mota, C.J.A., de Menezes, S.M.C. and Camorim, V.: 1994, NMR and acidity studies of dealuminated metakaolin and their correlation with cumene cracking. Applied Clay Science, 8, 321-330.

Meyer, U. and Hoelderich, W.F.: 1999, Application of basic zeolites in the decomposition reaction of 2-methyl-3butyn-2-ol and the isomerization of 3-carene. J. Mol. Catal. A: Chemical. 142 (2), 213-222.

DOI: $10.1016 / \mathrm{S} 1381-1169(98) 00289-1$

Novikova, L., Bel'chinskaya, L. and Roessner, F.: 2005, Influence of acid treatment on the surface properties of clay minerals. Sorption and chromatographic processes (Russia), 6, 798-805.

Novikova, L., Bel'chinskaya, L. and Roessner, F.: 2006, Effect of treatment with acids on the state of surface of natural clay minerals. Rus. J. Phys. Chem., 80 (1), 185-188. DOI: 10.1134/S0036024406130292

Matsuhashi, H., Motoi, H. and Arata, K.: 1994, Determination of acid strength of solid superacids by temperature programmed desorption using pyridine. Catal. Lett. 26 (3-4), 325-328. DOI: $10.1007 / \mathrm{BF} 00810605$

Okada, K., Arimitsu, N., Kameshima, Y., Nakajima, A. and MacKenzie, K.: 2006, Solid acidity of 2:1 type clay minerals activated by selective leaching. Appl. Clay Sci. 31, (3-4), 185-193. DOI: $10.1016 /$ j.clay.2005.10.014

Pushpaletha, P., Rugmini, S. and Lalithambika, M.: 2005, Correlation between surface properties and catalytic activity of clay catalysts. Appl. Clay Sci. 30, (3-4), 141-153. DOI: 10.1016/j.clay.2005.03.011
Ravichandran, J., Lakshmanan, C.M. and Sivasankar, B.: 1996, Acid activated montmorillonite and vermiculite clays as dehydration and cracking catalysts. Reac. Kinet.\&Catal. Let., V. 59 (2), 301-308. DOI: $10.1007 / \mathrm{BF} 02068127$

Ravichandran, J. and Sivasankar, B.: 1997, Properties and catalytic activity of acid-modified montmorillonite and vermiculite. Clay. Clay. Miner., 45 (6), 854-858. DOI: 10.1346/CCMN.1997.0450609

Ruiz, J.A.C., Melo, D.M.A., Souza, J.R. and Alcazar, L.O.: 2002, Determination of Total Acid in Palygorskite Chemically Modified by N-Butylamine Thermodesorption, Materials research, 5 (2), 173-178. DOI: $10.1590 / \mathrm{S} 1516-14392002000200014$

Sarikaya, Y., Oenal, M., Baran, B. and Alemdaroglu, T.: 2000, The effect of thermal treatment on some of the physicochemical properties of a bentonite. Clay. Clay. Miner., 48 (5), 557-562. DOI: $10.1346 / C C M N .2000 .0480508$

Sawalha, M.: 2004, Characterization of acidic and basic properties of heterogeneous catalysts by test reactions. Ph.D. thesis, Carl von Ossietzky Universitat, Oldenburg, Germany, $127 \mathrm{pp}$.

Schoonheydt, R.A. and Johnston, C.T.: 2006, Surface and interface chemistry of clay minerals in: Bergaya, F., Theng, B.K.G., Lagaly, G., 2006. Handbook of Clay Science. Developments in Clay Science, 1. Elsevier Ltd., 87-113.

Sun Kou, M.R., Mendioroz, S. and Mucoz, V.: 2000, Evaluation of the acidity of pillared montmorillonites by pyridine adsorption. Clay. Clay. Miner. 48 (5), 528-536. DOI: 10.1346/CCMN.2000.0480505

Tarasevich, Yu.I., 1988. Structure and chemistry of surface of layered silicates (in Russian), Naukova Dumka Kiev, 248 pp.

Topsoe, N.Y., Pedersen, K. and Derouane, E. G.: 1981, Infrared and temperature-programmed desorption study of the acidic properties of ZSM-5-type zeolites. J. Catal., 70, 41-52. DOI: 10.1016/0021-9517(81)90315-8

Trombetta, M., Busca, G., Lenarda, M., Storano, L., Ganzerla, R., Piovesan, L., Lopez, A.J. AlcantaraRodriduez, M. and Rodriguez-Castellon, E.: 2000, Solid acid catalysts from clays: evaluation of surface acidity of mono- and bi-pillared smectites by FT-IR spectroscopy measurements, $\mathrm{NH}_{3}$-TPD and catalytic tests. Appl. Catal., A Gen. 193, 55-69.

DOI: 10.1016/S0926-860X(99)00413-5

Yuan, P., Wu, D.Q., He, H.P. and Lin, Z.Y.: 2004, The hydroxyl species and acid sites on diatomite surface: a combined IR and Raman study. Appl. Surf. Sci. 227, 30-39. DOI: 10.1016/j.apsusc.2003.10.031

Wei, Z., Moldowan, M.J. and Dahl, J., Goldstein,T. P. and Jarvie, D.M.: 2006, The catalytic effects of minerals on the formation of diamondoids from kerogen macromolecules. Organic Geochemistry, 37 (11), 1421-1436. DOI: 10.1016/j.orggeochem.2006.07.006 